\author{
dr Marcin KARDAS \\ Wydział Zarządzania, Uniwersytet Warszawski \\ e-mail:mkardas@wz.uw.edu.pl
}

DOI: 10.15290/ose.2017.02.86.04

\title{
WSPÓŁZARZĄDZANIE WIELOPOZIOMOWE W POLITYCE INNOWACYJNEJ W POLSCE
}

\begin{abstract}
Streszczenie
Celem niniejszego artykułu jest przedstawienie zmian związanych z współzarządzaniem wielopoziomowym w polityce innowacyjnej w Polsce po 1989 roku. Kluczowe znaczenie w tym zakresie miały reformy administracyjne $z$ lat dziewięćdziesiątych minionego wieku oraz przystapienie Polski do Unii Europejskiej. Mimo rosnącego znaczenia poziomu ponadnarodowego i regionalnego w polityce innowacyjnej, z perspektywy wielkości środków przeznaczanych na finansowanie badań i innowacji oraz oddziaływania poprzez instrumenty pozafinansowe (legislacyjne) dominującą rolę nadal odgrywa poziom krajowy. Poziom regionalny polityki innowacyjnej przede wszystkim wiąże się z programowaniem i wdrażaniem wsparcia w ramach Regionalnych Programów Operacyjnych, współfinansowanych z funduszy pochodzących z Unii Europejskiej. W najbliższych latach istotne znaczenie dla współzarządzania wielopoziomowego w polityce innowacyjnej w Polsce będzie miało zapewnienie odpowiedniej koordynacji i spójności systemu wsparcia publicznego oraz zapewnienie stabilnych ram finansowych dla inicjatyw i działań realizowanych po 2020 roku na różnych poziomach, zwłaszcza na poziomach: regionalnym i lokalnym.
\end{abstract}

Słowa kluczowe: współzarządzanie wielopoziomowe, polityka innowacyjna, innowacje, badania naukowe

\section{MULTI-LEVEL GOVERNANCE IN INNOVATION POLICY IN POLAND}

\section{Summary}

The purpose of this paper is to present changes associated with multi-level governance in innovation policy in Poland after 1989. The administrative reforms of the 1990s and Poland's accession to the European Union played a crucial role in this respect. Despite the growing importance of transnational and regional levels, from the perspective of the scale of resources earmarked for research and innovation as well as impact of non-financial (legislative) instruments, the critical role is still played by national actors. The regional innovation policy is strongly dependent on financial support from the European Union. In the coming years, it will be vital for multi-level governance innovation policy in Poland to ensure proper coordination and coherence of the public support system and provide a stable financial framework for initiatives and activities implemented at various levels after 2020, especially at the regional and local levels.

Key words: multi-level governance, innovation policy, innovation, research and development

JEL: O38 


\section{Wstęp}

Wzrost popularności innowacji oraz działalności innowacyjnej przekłada się na wzrost zainteresowania polityką innowacyjna, która dla wielu państw i organizacji międzynarodowych staje się jedną z najważniejszych polityk publicznych. Działania na rzecz wsparcia innowacyjności są realizowane na różnych poziomach, tj.: ponadnarodowym, krajowym, regionalnym i lokalnym (miast). Ponadto, w tworzenie i wdrażanie polityki innowacyjnej jest włączanych coraz więcej podmiotów, w tym przedsiębiorcy i organizacje pozarządowe, zaś władze publiczne przyjmują rolę mediatora lub moderatora ich aktywności [Kuhlmann, 2001, s. 961; Edquist, Borras, 2013, s. 4]. Taki system sprawowania rządów w polityce innowacyjnej określa się jako współzarządzanie wielopoziomowe [Kuhlmann, 2001, s. 956, 966; Kopyciński, 2014, s. 223]. Zmiany związane $\mathrm{z}$ wielopoziomowością i partnerstwem w polityce innowacyjnej w odmienny sposób kształtują się w każdym państwie. Zróżnicowanie to wynika ze specyficznych uwarunkowań: społeczno-gospodarczych, polityczno-historycznych, kulturowych i geograficznych państw, a także uwarunkowań międzynarodowych, w tym stopnia intensyfikacji współpracy międzynarodowej w zakresie badań i innowacji. W efekcie nie ma jednego i uniwersalnego modelu (wzorca) współzarządzania wielopoziomowego w polityce innowacyjnej [Regions and Innovation Policy, 2011, s. 116; The Innovation Imperative, 2015, s. 238].

Zmiany związane z współzarządzaniem wielopoziomowym dotyczą różnych polityk publicznych, również w Polsce [Kozak, 2013, s. 42; Frączek, 2014, s. 25; Kopyciński, 2014, s. 223]. Celem niniejszego artykułu jest przedstawienie zmian w polityce innowacyjnej z perspektywy współzarządzania wielopoziomowego, w szczególności działań podejmowanych w Polsce po 1989 roku w zakresie wspierania innowacyjności na poziomach: ponadnarodowym, krajowym, regionalnym i lokalnym. W pierwszej części przedstawiono kwestie teoretyczne związane $z$ definicją i podziałami współzarządzania wielopoziomowego. Następnie omówiono proces zmian i ewolucji oraz specyficzne uwarunkowania obejmujące współzarządzanie wielopoziomowe w polityce innowacyjnej w Polsce. W końcowej części podsumowano przeprowadzone analizy oraz opisano główne wyzwania wynikające ze współzarządzania wielopoziomowego w krajowej polityce innowacyjnej. W artykule wykorzystano metodę analizy dokumentów i krytyki piśmiennictwa. Oparto się na pierwotnych i wtórnych źródłach informacji, w tym dokumentach strategicznych i aktach prawnych.

\section{Współzarządzanie wielopoziomowe w polityce innowacyjnej}

Współzarządzanie, współrządzenie lub zarządzanie wielopoziomowe (ang. multi-level governance - MLG) ${ }^{1}$ można zdefiniować jako system ciagłych negocjacji między rządami

${ }^{1}$ W literaturze krajowej przyjmuje się różne tłumaczenia tego terminu, co szczegółowo omówili m.in. J. Ruszkowski [2013, s. 7] i J. Hausner [2008, s. 403]. W oficjalnych tłumaczeniach dokumentów unijnych są stosowane rozmaite zwroty, np.: zarządzanie wielopoziomowe (wieloszczeblowe), wielopoziomowe sprawowanie rządów lub wielopoziomowy system rządzenia. W krajowej literaturze jest również stosowana 
na kilku poziomach, będący rezultatem szerszego procesu tworzenia instytucji i realokacji decyzji wcześniej scentralizowanych na poziomie narodowym „w górę” na poziom ponadnarodowy oraz „,w dół" na poziom regionalny lub lokalny [Marks, 1993, s. 392]. Schmitter [2002, s. 6] definiuje współzarządzanie wielopoziomowe jako porządek (układ) podejmowania wiążących decyzji, w ramach którego różnorodni aktorzy publiczni i prywatni, niezależni jak i współzależni politycznie, działający na różnych poziomach terytorialnej agregacji, angażowani są do ciąłych negocjacji oraz działań implementacyjnych, tak że nie da się przypisać żadnemu z poziomów wyłącznej kompetencji lub dominującej władzy politycznej. Piattoni [2009, s. 17] zauważa, że dany proces wpisuje się w współzarządzanie wielopoziomowe, jeśli zostaną spełnione następujące warunki:

- $\quad$ różne poziomy rządów są równocześnie włączone w proces polityczny;

- $\quad$ na rozmaitych poziomach w procesy polityczne są włączeni aktorzy spoza rządów;

- $\quad$ współzależności między różnorodnymi poziomami a aktorami przyjmuja głównie formę niehierachicznych sieci i ignorują istniejące hierarchie.

Według OECD [The Innovation Imperative, s. 237], współzarządzanie wielopoziomowe oznacza dostosowanie politycznych działań między różnymi ministerstwami, agencjami i interesariuszami oraz między różnymi poziomami rządzenia, także ponad granicami państw. Współzarządzanie wielopoziomowe zyskało szczególnie dużą popularność w Unii Europejskiej, gdzie początkowo było związane z funduszami strukturalnymi, ale z czasem zaczęto je stosować do Unii Europejskiej jako całości [Hooghe, Marks, 2003, s. 234]. Zgodnie z art. 5 Rozporzqdzenia 1303/2013 z. 17 grudnia 2013 roku (Dz. U. UE L 347/320 z dnia 20.12.2013), partnerstwo i zarządzanie wielopoziomowe stanowia podstawowe zasady wsparcia $z$ europejskich funduszy strukturalnych i inwestycyjnych (ESIF). Komitet Regionów w „Karcie Wielopoziomowego Sprawowania Rządów” [Rezolucja w sprawie..., 2014, s. 3] wskazał, że podstawą wielopoziomowych rządów w Europie powinny być: skoordynowane driałania Unii, panstw członkowskich $i$ władz lokalnych $i$ regionalnych, opierajace sie na zasadach pomocniczości, proporcjonalności i partnerstwa, które przejawiaja sie w operacyjnej $i$ zinstytucjonalizowanej wspótpracy na rzecz. opracowywania $i$ realizacji polityk Unii Europejskiej. W tabeli 1. przedstawiono podstawowe zasady i działania odnoszace się do współrządzenia, wynikające z Karty Wielopoziomowego Sprawowania Rzadów.

wersja anglojęzyczna tego terminu [Kozak, 2013, s. 27]. W niniejszym opracowaniu przyjęto termin współzarządzanie wielopoziomowe, gdyż podkreśla ono zabarwienie społeczne tego sformułowania oraz wskazuje na realizację działań na kilku poziomach [Kopyciński, 2014, s. 35]. 
TABELA 1.

Podstawowe zasady oraz wdrażanie i realizacja wielopoziomowego sprawowania rządów, według Karty Wielopoziomowego Sprawowania Rządów

\begin{tabular}{|l|l|}
\hline \multicolumn{1}{|c|}{ Podstawowe zasady } & \multicolumn{1}{c|}{ Wdrażanie i realizacja } \\
\hline $\begin{array}{l}\text { Wypracowanie przejrzystego, otwartego i anga- } \\
\text { zującego wszystkie strony procesu decyzyjnego. }\end{array}$ & $\begin{array}{l}\text { Promowanie uczestnictwa obywateli w cyklu } \\
\text { politycznym. }\end{array}$ \\
\hline $\begin{array}{l}\text { Promowanie uczestnictwa i partnerstwa włącza- } \\
\text { jącego w cały proces decyzyjny odpowiednie, } \\
\text { publiczne i prywatne, zainteresowane strony. }\end{array}$ & $\begin{array}{l}\text { Ścisła współpraca z innymi władzami publiczny- } \\
\text { mi oparta na podejściu wykraczającym poza: } \\
\text { tradycyjne granice, procedury i przeszkody ad- } \\
\text { ministracyjne. }\end{array}$ \\
\hline $\begin{array}{l}\text { Propagowanie skuteczności i spójności polityki } \\
\text { oraz wspieranie synergii budżetowej między wszys- } \\
\text { tkimi poziomami sprawowania rząów. }\end{array}$ & $\begin{array}{l}\text { Wspieranie nastawienia europejskiego organów } \\
\text { politycznych i administracyjnych. }\end{array}$ \\
\hline $\begin{array}{l}\text { Przestrzeganie zasad pomocniczości i proporcjo- } \\
\text { nalności w ramach procesu decyzyjnego. }\end{array}$ & $\begin{array}{l}\text { Wzmocnienie procesu budowania zdolności } \\
\text { instytucjonalnych oraz inwestowania we wza- } \\
\text { jemne uczenie się. }\end{array}$ \\
\hline $\begin{array}{l}\text { Zapewnienie jak największej ochrony praw pod- } \\
\text { stawowych na wszystkich poziomach sprawowa- } \\
\text { nia rządów. }\end{array}$ & $\begin{array}{l}\text { Tworzenie sieci organów politycznych i admi- } \\
\text { nistracyjnych: od poziomu lokalnego, po euro- } \\
\text { pejski i odwrotnie, a jednocześnie zacieśnianie } \\
\text { współpracy transnarodowej. }\end{array}$ \\
\hline
\end{tabular}

Źródło: [Rezolucja w sprawie Karty Wielopoziomowego Sprawowania Rzqdów..., 2014, s. 4, 5].

Państwa i regiony różnią się pod względem poziomu zaawansowania współzarzadzania wielopoziomowego w polityce innowacyjnej [Regions and Innovation Policy, 2011, s. 116]. Generalnie, im większa polityczna autonomia regionów, tym silniej wyróżniają się elementy regionalnych systemów innowacji i regionalne polityki innowacyjne. Przykładami regionów, które tworzą i wdrażaja politykę innowacyjną, są m.in. landy w Niemczech czy Kraj Basków w Hiszpanii [Kuhlmann, 2001, s. 960; Magro, Wilson, 2013, s. 1651]. Jednak w tym samym państwie regiony w różnorodnym stopniu mogą wykorzystywać możliwości w zakresie tworzenia i wdrażania własnej polityki innowacyjnej, zaś różnice te są określane mianem asymetrycznej decentralizacji oraz są wynikiem zróżnicowanego potencjału regionów i dostępnych zasobów, zwłaszcza finansowych [Regions and Innovation Policy, 2011, s. 119]. Cooke [2002, s. 136] wskazuje, że współrządzenie wielopoziomowe w odniesieniu do polityki innowacyjnej zależy od następujących pięciu czynników:

- $\quad$ obecności i pozycji regionalnych struktur władzy;

- $\quad$ możliwości wsparcia ze strony licznych i zróżnicowanych regionalnych oraz lokalnych innowacyjnych organizacji;

- $\quad$ interakcji między firmami a innymi organizacjami na poziomie regionalnym i ponadregionalnym;

- $\quad$ istnienia regionalnych polityk i programów badań, a także innowacji wspieranych z poziomu krajowego i europejskiego;

- dostępu do źródeł finansowania działalności innowacyjnej regionalnych firm i organizacji. 
Współzarządzanie wielopoziomowe wiąże się z ponadnarodową integracją albo decentralizacją (regionalizacja) pewnych działań, realizowanych wcześniej na poziomie krajowym. Rodzi to pytanie, jakie zadania z zakresu tej polityki powinny być realizowane na różnych szczeblach sprawowania rządów. W tabeli 2. zostały przedstawione dwa ekstrema (centralizacji i decentralizacji), między którymi są dokonywane wybory w polityce innowacyjnej.

TABELA 2.

\section{Centralizacja i decentralizacja w polityce innowacyjnej}

\begin{tabular}{|c|c|c|}
\hline Przedmiot wyboru & $\begin{array}{c}\text { Centralizacja } \\
\text { (poziom europejski i krajowy) }\end{array}$ & $\begin{array}{c}\text { Decentralizacja } \\
\text { (poziom regionalny i lokalny) }\end{array}$ \\
\hline $\begin{array}{l}\text { Podstawowy cel i kryte- } \\
\text { rium oceny wniosków }\end{array}$ & $\begin{array}{l}\text { Doskonałość (wysoka jakość) na- } \\
\text { ukowa, konkurencyjność między- } \\
\text { narodowa. }\end{array}$ & $\begin{array}{l}\text { Spójność i rozwój regionalny, po- } \\
\text { prawa warunków i jakości życia. }\end{array}$ \\
\hline $\begin{array}{l}\text { Zakres przedmiotowy } \\
\text { wsparcia }\end{array}$ & $\begin{array}{l}\text { Badania naukowe (podstawowe } \\
\text { i stosowane) i prace rozwojowe. }\end{array}$ & $\begin{array}{l}\text { Prace rozwojowe i wdrożenia wy- } \\
\text { ników badań. }\end{array}$ \\
\hline $\begin{array}{l}\text { Charakter wspieranych } \\
\text { przedsięwzięć }\end{array}$ & Innowacje przełomowe. & $\begin{array}{l}\text { Innowacje inkrementalne (przy- } \\
\text { rostowe). }\end{array}$ \\
\hline Forma wsparcia & Dotacje. & $\begin{array}{l}\text { Instrumenty zwrotne (kredyty, } \\
\text { pożyczki). }\end{array}$ \\
\hline Beneficjenci & $\begin{array}{l}\text { Naukowcy i jednostki naukowe, } \\
\text { przedsiębiorstwa zaawansowane } \\
\text { w prowadzeniu prac badawczo- } \\
\text { rozwojowych. }\end{array}$ & $\begin{array}{l}\text { Przedsiębiorstwa, głównie małe } \\
\text { i średnie, instytucje otoczenia biz- } \\
\text { nesu. }\end{array}$ \\
\hline Uzasadnienie interwencji & $\begin{array}{l}\text { Tworzenie tzw. masy krytycznej } \\
\text { (realizacja dużych, kosztownych, } \\
\text { przełomowych i ryzykownych } \\
\text { przedsięwzięć oraz projektów). }\end{array}$ & $\begin{array}{l}\text { Wzmacnianie zdolności absorp- } \\
\text { cyjnych i wspieranie dyfuzji in- } \\
\text { nowacji. }\end{array}$ \\
\hline Ryzyko podejść & $\begin{array}{l}\text { Marginalizacja uwarunkowań re- } \\
\text { gionalnych, nieuwzględnianie spe- } \\
\text { cyficznych potrzeb regionalnych. } \\
\text { Prymat „efektywności” nad „,rów- } \\
\text { nością" w kontekście prowadze- } \\
\text { nia polityki regionalnej. }\end{array}$ & $\begin{array}{l}\text { Brak odpowiednich zasobów, } \\
\text { umiejętności i kwalifikacji po } \\
\text { stronie instytucji udzielających } \\
\text { wsparcia na różnych poziomach. } \\
\text { Rozdrobnienie (fragmentacja) } \\
\text { działań i ich powielanie w róż- } \\
\text { nych państwach lub regionach. }\end{array}$ \\
\hline
\end{tabular}

Źródło: opracowanie własne.

Nie ma jednego wzorca lub uniwersalnego modelu, który stanowiłby odpowiedź na poszczególne zagadnienia, będące przedmiotem wyborów, a te przedstawiono w tabeli 2. Zwykle w każdym państwie działania zmierzają w kierunku poszukiwania rozwiązań pośrednich. Centralizowane są zadania i związane z nimi: instrumenty dotyczące wsparcia badań: naukowych, naukowców i doktorantów; współpraca międzynarodowa; utrzymanie potencjału naukowego (przykładowo tzw. dotacje statutowe); utrzymanie jakości i usług metrologicznych oraz normalizacji. Natomiast zadania i instrumenty związane ze: wsparciem wdrożeń wyników badań, z usługami doradczymi, tworze- 
niem start-upów oraz infrastruktury wsparcia biznesu (np.: inkubatory, parki technologiczne) są decentralizowane [Regions and Innovation Policy, 2011, s. 124].

W literaturze wskazuje się na wiele wyzwań związanych z współzarządzaniem wielopoziomowym. Większa liczba podmiotów sektora publicznego, zaangażowanych w sprawowanie rządów na różnych poziomach, niesie ze sobą ryzyko rozdrobnienia działań, co może ograniczać i utrudniać procesy koordynacji i uczenia się (ang. policy learning) oraz może powodować rozmycie odpowiedzialności za realizowane działania [Bonaccorsi, 2009, s. 14]. Dyskusyjna jest kwestia kosztów związanych z funkcjonowaniem złożonego i wielopłaszczyznowego systemu wsparcia badań i innowacji [Koschatzky, Kroll, 2009, s. 57]. Wskazuje się również, że przejmowanie pewnych działań, dotyczących polityki innowacyjnej na poziom europejski oraz przekazywanie innych na poziom regionalny, prowadzi do osłabienia pozycji rządów narodowych [Rodrigo, Allio, Andres-Amo, 2009; The Innovation Imperative, 2015, s. 238]. W efekcie współzarządzanie wielopoziomowe w wielu państwach stało się przedmiotem ożywionej debaty politycznej.

\section{Współzarządzanie wielopoziomowe w polityce innowacyjnej w Polsce}

W Polsce ewolucja systemu wsparcia innowacji w kierunku współzarządzania wielopoziomowego została zapoczątkowana przez zmiany związane z transformacją ustrojową na początku lat dziewięćdziesiątych minionego wieku. W latach 1945-1989 rozwój przemysłu był planowany centralnie i nastawiony na wyniki ilościowe, zaś państwo brało na siebie cały ciężar spraw obejmujących regulację i przebieg procesów innowacyjnych, odsuwając mechanizmy rynkowe na plan dalszy [Præeglad Narodowej Polityki Naukowej..., 1996, s. 21; Jasiński, 1997, s. 159, 168]. Zlikwidowano samorząd regionalny, natomiast układ regionalny i lokalny były traktowane jako szczebel administracji i narzędzie w rękach władz centralnych [Szlachta, 1993, s. 8; Miedziński, 2001, s. 213]. Transformacja ustrojowa zapoczątkowała istotne zmiany w zakresie wspierania badań $\mathrm{i}$ innowacji, w tym kształtowania się wielopoziomowego systemu sprawowania rządów w polityce innowacyjnej. Pod tym względem kluczowymi wydarzeniami były reformy administracyjne oraz przystapienie Polski do Unii Europejskiej. Na tej podstawie wyróżniono trzy etapy kształtowania się współzarządzania wielopoziomowego w polityce innowacyjnej w Polsce.

\section{Etap I: pierwsze lata transformacji ustrojowej - wyłanianie się polityki inno- wacyjnej (1989-1998)}

W 1989 roku rozpoczęto prace nad zmianami systemu finansowania badań, których efektem była likwidacja Komitetu do spraw Nauki i Postępu Technicznego oraz Urzędu Postępu Naukowo-Technicznego i Wdrożeń [Jabłecka, 2009, s. 107], a także utworzenie w styczniu 1991 roku Komitetu Badań Naukowych (KBN). Komitet Badań Naukowych odgrywał podwójną rolę, tzn. Ministerstwa do spraw Badań i Technologii (zadania strategiczne) oraz organu finansującego sferę badawczo-rozwojową i realizującego zadania wykonawcze [Jasiński, Okoń-Horodyńska, 2002, s. 129]. Większość człon- 
ków KBN była wybierana spośród środowiska naukowego w wyborach powszechnych, stąd KBN nie był typowym ciałem rządowym [Pręglad Narodowej Polityki Naukowej..., 1996, s. 24, 144]. Na przełomie 1990 i 1991 roku utworzono również Fundację na rzecz Nauki Polskiej (FNP), która przejęła część środków z Centralnego Funduszu Rozwoju Nauki i Techniki. Zadaniem FNP było wspieranie badań naukowych, wybieranych w trybie konkursowym oraz na podstawie kryterium doskonałości naukowej. Z kolei, resortem odpowiedzialnym za zagadnienia związane z rozwojem przemysłu było Ministerstwo Przemysłu i Handlu (w 1997 roku przekształcone w Ministerstwo Gospodarki). W 1993 roku utworzono Polską Agencję Rozwoju Regionalnego (PARR), której zadaniem było udzielanie wsparcia na rzecz rozwoju regionalnego oraz upowszechnianie standardów Unii Europejskiej w zakresie wdrażania programów rozwoju regionalnego, w 1995 roku Fundację Promocji i Rozwoju Małych i Średnich Przedsiębiorstw (FPRMSP), a w 1996 roku Agencję Techniki i Technologii (ATT). Działalność PARR, FPRMSP i AT'T w dużej części była finansowana z funduszy pomocowych pochodzacych z Unii Europejskiej, np. programu Phare. Pierwsze lata transformacji systemowej przyniosły także istotne zmiany w zakresie samorządu terytorialnego. W 1990 roku przywrócono samorządy terytorialne na szczeblu miast i gmin, co miało bardzo duże znaczenie dla odtworzenia podmiotowości społeczności lokalnych, natomiast szczebel regionalny (49 województw) pozostał domeną administracji państwowej [Szlachta, 1993, s. 81]. Od 1991 roku przez administrację rządową i samorządową były tworzone agencje rozwoju regionalnego (spółki prawa handlowego lub fundacje) bądź lokalnego. W 1997 roku działało ich ponad 60 [Gorzelak i in. 1997, s. 335]. Celem agencji rozwoju regionalnego było wsparcie rozwoju ekonomicznego regionów, w tym wspieranie procesów restrukturyzacyjnych przedsiębiorstw. Jednym z ich głównych partnerów była Agencja Rozwoju Przemysłu SA (spółka Skarbu Państwa utworzona w 1991 roku w celu wsparcia procesów restrukturyzacyjnych przedsiębiorstw), z której wsparcia korzystała co druga agencja rozwoju regionalnego [Gorzelak i in. 1997, s. 341].

W pierwszych latach transformacji systemowej nie przyjęto rządowego programu polityki naukowej i technicznej, zaś zmiany wprowadzone w tych latach ujawniły podejście neoliberalne, znacznie ograniczające rolę państwa w polityce gospodarczej, czego wyrazem była likwidacja większości, wcześniej stosowanych, preferencji i działań państwa [Jasiński, 1997, s. 160]. Pierwsze programy rządowe w tym zakresie stanowiły ,Założenia polityki naukowej i naukowo-technicznej państwa” z 1993 roku (przygotowane przez KBN) oraz „Założenia polityki proinnowacyjnej państwa” z 1994 roku, które zostały opracowane przez specjalnie powołany w tym celu zespół międzyresortowy na podstawie wyników diagnozy stanu stworzonych przez niezależne zespoły badawcze. Dokumenty te określały zestaw zadań i narzędzi oraz były pierwszą tak kompleksową formą w procesie transformacji polskiej gospodarki [Okoń-Horodyńska, 1998, s. 218]. Mimo wielu niedoskonałości, stanowiły one postęp w stosunku do dokumentów z początku lat dziewięćdziesiątych minionego wieku, tworząc podwaliny pod politykę innowacyjną w Polsce [Jasiński, 1997, s. 165]. W 1997 roku Rada Ministrów przyjęła dokument pt.: „Program wspierania rozwoju instytucji regionalnych działających na rzecz transferu technologii” (przygotowany przez Ministerstwo Gospodarki), którego celem był rozwój innowacyjności małych i średnich przedsiębiorstw przez intensyfikację trans- 
feru nowoczesnych, proekologicznych technologii. Zgodnie z wyżej wymienionym programem, regionalny system innowacyjny miał być rozwijany w trzech kierunkach, tj:: organizacji infrastruktury instytucjonalnej, rozwoju systemu finansowania i zarządzania innowacjami, a także pobudzania popytu i przedsiębiorczości w sferze zaawansowanych technologii. W programie z 1997 roku określono dwanaście zadań wdrożeniowych, przy czym jedenaście z nich miało być realizowanych centralnie, zaś jedno było adresowane do wojewodów, tj. monitorowanie zmian i powiązań instytucji działających na rzecz innowacyjności na szczeblu regionalnym [Program wspierania rozwoju..., 1997, s. 28-33].

Transformacja systemowa umożliwiła udział Polski w różnych organizacjach międzynarodowych oraz zapoczątkowała proces integracji z Unią Europejską w obszarze badań i innowacji. W grudniu 1991 roku został podpisany Układ Stowarzyszeniowy między Polską a Wspólnotami Europejskimi [Przeglad Narodowej Polityki Naukowej..., 1996, s. 119]. Od 1990 roku Polska stała się członkiem Europejskiej Organizacji Badań Jądrowych (CERN), choć polscy naukowcy już wcześniej uczestniczyli w pracach tej organizacji, a w 1991 roku Europejskiej Fundacji Naukowej (ESF) i Europejskiego Programu Współpracy w dziedzinie Badań Naukowo-Technicznych (COST). Od 1994 roku Polska współpracowała z Europejską Agencją Kosmiczna (ESA), a w 1996 roku stała się członkiem OECD [Præzeglad Narodowej Polityki Nankowej..., 1996, s. 118-119].

Reasumując, pierwsze lata transformacji ustrojowej były okresem wyłaniania się na poziomie krajowym polityki innowacyjnej jako odrębnego obszaru polityki państwa i aktywności władz publicznych, czego efektem były pierwsze dokumenty strategiczne $(1993$, 1994) oraz ramy instytucjonalne tej polityki (FNP, PARR, FPRMSP, ATT). Słabościa powstającego systemu wsparcia innowacji był brak spójności instytucjonalnej między koncepcjotwórcami (KBN i FNP) a mocodawcami polityki innowacyjnej w Polsce (Ministerstwo Finansów i Ministerstwo Przemysłu i Handlu/Gospodarki), jak również rozmycie funkcji koordynacyjnej [Okoń-Horodyńska, 1998, s. 218]. Podobne słabości koordynacyjne na szczeblu centralnym dotyczyły polityki regionalnej, zaś jej prowadzenie dodatkowo utrudniał brak podmiotowości regionalnej, tj. podmiotu realizującego politykę intraregionalna [Gorzelak i in. 1997, s. 356; Szlachta, 1993, s. 92]. W okresie tym politykę regionalną kształtowały bieżące potrzeby przede wszystkim związane ze skutkami restrukturyzacji przedsiębiorstw, w tym wzrostem bezrobocia. Wprawdzie w pierwszej połowie lat dziewięćdziesiątych minionego wieku na poziomie dokumentów rządowych formułowano zasady nowoczesnej polityki regionalnej, ale ich wdrożenie nie było udane [Lodkowska-Skoneczna, 1999, s. 73-74]. Pierwsze lata transformacji nie przyniosły także większych zmian w zakresie roli województw w polityce innowacyjnej [Miedziński, 2001, s. 213], a wyłaniająca się polityka innowacyjna była scentralizowana oraz stanowiła domenę instytucji działajacych na poziomie krajowym.

\section{Etap II: reforma administracyjna i prace przedakcesyjne - wyłanianie się struktur wielopoziomowych w polityce innowacyjnej (1999-2003)}

Ze względu na współzarządzanie wielopoziomowe, w polityce innowacyjnej kluczowe znaczenie miała reforma administracyjna wprowadzona w 1999 roku, w wyniku 
której utworzono 16 rządowo-samorządowych województw (w miejsce 49 rządowych województw) oraz 315 samorządowych powiatów. Na mocy wyżej wymienionej reformy samorządy województw stały się odpowiedzialne za opracowanie strategii województw, których cel stanowiło pobudzanie aktywności gospodarczej oraz podnoszenie poziomu konkurencyjności i innowacyjności gospodarki województwa. Zadania samorządu województwa obejmowały prowadzenie polityki rozwoju województw, w tym wspieranie rozwoju nauki i wspólpracy między sferą nauki a gospodarki oraz popieranie postępu technologicznego i innowacji. Przy formułowaniu strategii rozwoju województwa i realizacji polityki rozwoju samorząd województwa został zobligowany do współpracy z: innymi jednostkami samorządu terytorialnego i samorządem gospodarczym i zawodowym, administracją rządową, organizacjami pozarządowymi, szkołami wyższymi i jednostkami naukowo-badawczymi. Współpraca w tym zakresie mogła także obejmować organizacje międzynarodowe oraz regiony innych państw, zwłaszcza sąsiednich. W ustawowym katalogu zadań samorządu województwa znalazły się m.in. zadania z zakresu edukacji publicznej, w tym szkolnictwa wyższego, chociaż nie było w nim zadań z zakresu polityki naukowej i innowacyjnej (realizacja wyżej wymienionych zadań na poziomie regionalnym wynika z Ustany z dnia 6 grudnia 2006 roku o zasadach prowadzenia rozwoju (t.j. Dz. U. 2014, poz. 1649 z późn. zm.), a dotyczy opracowywania i wdrażania Regionalnych Programów Operacyjnych).

Na poziomie krajowym zmianą instytucjonalną w systemie wsparcia badań i innowacji było utworzenie w 2000 roku Polskiej Agencji Rozwoju Przedsiębiorczości, która powstała na bazie Polskiej Fundacji Promocji i Rozwoju Małych i Średnich Przedsiębiorstw. Do PARP włączono również Agencję Techniki i Technologii oraz Polską Agencję Rozwoju Regionalnego. Początkowo zadaniem PARP było wspieranie: rozwoju małych i średnich przedsiębiorstw, eksportu, spójności społeczno-gospodarczej kraju. Za sprawą nowelizacji ustawy o utworzeniu PARP w 2002 roku do jej zadań dodano wsparcie w zakresie wykorzystania nowych technik i technologii. Polska Agencja Rozwoju Przedsiębiorczości podlegała Ministerstwu Gospodarki.

W końcu lat dziewięćdziesiątych minionego wieku działania z zakresu polityki innowacyjnej na poziomie krajowym były realizowane przez dwa ośrodki: KBN i Ministerstwo Gospodarki. Efektem tych działań były następujące dokumenty strategiczne związane z polityką innowacyjną:

- „Założenia polityki innowacyjnej państwa do 2002 roku” (opracowany przez KBN i w dniu 6 grudnia 1999 roku przyjęty przez Radę Ministrów) przewidywał m.in.: wsparcie finansowe i informacyjne podmiotów przystępujących do 5. programu ramowego Wspólnoty Europejskiej w dziedzinie badań, rozwoju technologicznego i demonstracji oraz uczestniczących w realizacji zadań tego programu; wspieranie inicjatyw regionalnych na rzecz rozwoju regionalnych systemów innowacyjnych, a także przygotowanie informacji o tworzeniu i funkcjonowaniu sieci regionalnych ośrodków koordynacji działań innowacyjnych, obejmujących sferę: nauki, prac badawczo-rozwojowych, transferu technologii; wspieranie przedsiębiorczości oraz edukacji;

- "Zwiększanie innowacyjności gospodarki w Polsce do 2006 roku” (opracowany przez Ministerstwo Gospodarki i w dniu 11 lipca 2000 roku przyjęty 
przez Radę Ministrów) przewidywał m.in. przekazanie odpowiedzialności za regionalne programy innowacyjne na rzecz samorządów województw czy wsparcie powstawania i działalności regionalnych centrów innowacji i transferu technologii.

Lata 1998-2003 stanowiły okres negocjacji akcesyjnych Polski z Unią Europejska. W związku z dostosowaniem procedur programowania polityki rozwoju do standardów Unii Europejskiej zostało opracowanych kilka dokumentów strategicznych, w tym: $\mathrm{Na}$ rodowa Strategia Rozwoju Regionalnego 2001-2006 [2000], Wstepny Narodowy Plan Rozwoju 2000-2003 [1999; 2002] oraz Narodowy Plan Rozwoju 2004-2006 [2003]. Celem NPR było rozwijanie konkurencyjnej gospodarki opartej na wiedzy i przedsiębiorczości, zdolnej do długofalowego, harmonijnego rozwoju, zapewniającej wzrost zatrudnienia oraz poprawę spójności społecznej, ekonomicznej i przestrzennej z Unią Europejską na poziomie regionalnym i krajowym. Wdrażanie NPR miało odbywać się przez sektorowe programy operacyjne, współfinansowane z funduszy strukturalnych Unii Europejskiej, w tym: „Sektorowy Program Operacyjny - Wzrost Konkurencyjności Przedsiębiorstw” (SPO WKP) oraz „Zintegrowany Program Operacyjny Rozwoju Regionalnego" (ZPORR). W ramach tego ostatniego przewidziano m.in. działanie ukierunkowane w stronę wzmocnienia regionalnej bazy ekonomicznej i zasobów ludzkich w zakresie regionalnych strategii innowacji [Narodony Plan Rozwoju..., 2003, s. 118].

Reforma administracyjna z 1999 roku stworzyła warunki do określania i wdrażania polityki innowacyjnej na poziomie regionalnym. W 2000 roku kilka regionów przystapiło do tworzenia regionalnych strategii innowacji. W Polsce pierwsze regionalne strategie innowacji powstawały głównie dzięki wsparciu finansowemu z Unii Europejskiej [Regions and Innovation Policy, 2011, s. 118]. Opracowanie pięciu regionalnych strategii innowacji (dla województw: wielkopolskiego, opolskiego, śląskiego, zachodniopomorskiego i warmińsko-mazurskiego) było dofinansowane z 5. programu ramowego Wspólnoty Europejskiej w zakresie: badań, rozwoju technologicznego i demonstracji, zaś kolejnych 10 regionów uzyskało dofinansowanie na tworzenie regionalnych strategii innowacji z KBN. W sumie do 2005 roku zostało opracowanych 15 regionalnych strategii innowacji. Regionalne strategie innowacji, podobnie jak 16 regionalnych strategii województw powstałych w 2000 roku, były niedoskonałe, ale podjęcie nad nimi, często szeroko zakrojonych, prac zwiększyło samoświadomość elit regionalnych i przyczyniło się do mobilizacji środowisk regionalnych na rzecz działań w obszarze innowacyjności. Słabością wielu regionalnych strategii innowacji był natomiast brak struktur zarządzania wdrażaniem tych strategii oraz brak instrumentów interwencji służących realizacji zakładanych celów [Gorzelak i in. 2006, s. 165-167; Nowakowska, 2009, s. 209].

Podsumowując, reforma administracyjna z 1999 roku stała się podstawą do tworzenia i realizacji polityki innowacyjnej na poziomie regionalnym, w tym przesłanki dla ograniczenia polityki międzyregionalnej uprawianej na poziomie centralnym, jak również umożliwiła stosowanie zasady subsydiarności [Dziemianowicz i in. 1999, s. 39]. Podjęte zostały prace nad regionalnymi strategiami innowacji w 15 regionach. Przeprowadzono negocjacje dotyczące przystapienia Polski do Unii Europejskiej oraz zostały opracowane dokumenty wyznaczające zasady wykorzystania funduszy strukturalnych w pierwszych latach po przystapieniu Polski do Unii Europejskiej, w tym środków na wspar- 
cie badań i innowacji (np.: NPR, SPO WKP, ZPORR). W wymiarze programowym, dokumenty strategiczne związane z polityką innowacyjna były opracowywane przez KBN i Ministerstwo Gospodarki, co rodziło instytucjonalny dualizm w zakresie tworzenia i wdrażania tej polityki oraz brak jasnego podziału kompetencji między tymi instytucjami [Jasiński, 2006, s. 194].

\section{Etap III: członkostwo Polski w Unii Europejskiej i reformy instytucjonalne w systemie wsparcia badań $i$ innowacji (od 2004 roku)}

Przystąpienie w 2004 roku Polski do Unii Europejskiej umożliwiło udział na pełnych zasadach w tworzeniu tzw. europejskiej polityki innowacyjnej (np.: współpracy w ramach Europejskiego Instytutu Innowacji i Technologii czy Europejskiej Mapy Drogowej Infrastruktury Badawczej, wspólnych dla państw Unii rozwiązań prawnych (np. patent europejski o jednolitym skutku) bądź standardów postępowania (np. Europejska Karta Naukowca) oraz korzystaniu z programów wsparcia badań i innowacji na poziomie europejskim (np.: 7. program ramowy Wspólnoty Europejskiej w zakresie badań i rozwoju technologicznego, program „Horyzont 2020” i program COSME). Z drugiej strony obecność Polski w Unii Europejskiej wiąże się z dostępem do środków pochodzących z funduszy strukturalnych i polityki spójności (obecnie europejskich funduszy strukturalnych i inwestycyjnych). Dzięki tym ostatnim, Polska stała się beneficjentem znacznych środków na badania i innowacje, które w latach 2004-2006 i 2007-2013 wynosiły około 1,54 mld euro i 11,1 mld euro, zaś w latach 2014-2020 wyniosą około 19 mld euro. Zestawienie programów operacyjnych i przewidywane w nich alokacje na badania i innowacje przedstawia tabela 3 .

TABELA 3.

Programy operacyjne wspierające badania i innowacje w Polsce

\begin{tabular}{|c|c|c|c|}
\hline & $2004-2006$ & $2017-2013$ & 2014-2020 \\
\hline $\begin{array}{l}\text { Poziom } \\
\text { krajowy }\end{array}$ & $\begin{array}{l}\text { - Sektorowy Program Opera- } \\
\text { cyjny Wzrost Konkurencyj- } \\
\text { ności Przedsiębiorstw (SPO } \\
\text { WKP, około } 1 \text { mld euro) } \\
\text { - Zintegrowany Program Opera- } \\
\text { cyjny Rozwoju Regionalnego } \\
\text { (ZPORR, około 0,54 mld euro) }\end{array}$ & $\begin{array}{l}\text { - Program Operacyjny In- } \\
\text { nowacyjna Gospodarka } \\
\text { (POIG, około 6,3 mld } \\
\text { euro) } \\
\text { - Program Operacyjny In- } \\
\text { frastruktura i Środowisko } \\
\text { - (POIiŚ, około 0,6 mld } \\
\text { euro) }\end{array}$ & $\begin{array}{l}\text { - Program Operacyjny } \\
\text { Inteligentny Rozwój } \\
\text { (POIR, około 8,3 mld } \\
\text { euro) } \\
\text { - Program Rozwoju } \\
\text { Obszarów Wiejskich } \\
\text { (PROW, około 4,1 } \\
\text { mld euro) }\end{array}$ \\
\hline $\begin{array}{l}\text { Poziom } \\
\text { ponadregionalny }\end{array}$ & - & $\begin{array}{l}\text { - Program Operacyjny Roz- } \\
\text { wój Polski Wschodniej } \\
\text { (PO RPW, około 0,5 mld } \\
\text { euro) }\end{array}$ & $\begin{array}{l}\text { - Program Operacyjny } \\
\text { Polska Wschodnia } \\
\text { (PO PW, około 0,7 } \\
\text { mld euro) }\end{array}$ \\
\hline $\begin{array}{l}\text { Poziom } \\
\text { regionalny }\end{array}$ & - & $\begin{array}{l}\text { - } 16 \text { Regionalnych Prog- } \\
\text { ramów Operacyjnych } \\
\text { (RPO, około 3,7 mld eu- } \\
\text { ro) }\end{array}$ & $\begin{array}{l}\text { - } 16 \text { Regionalnych Prog- } \\
\text { ramów Operacyjnych } \\
\text { (RPO, około 5,9 mld } \\
\text { euro) }\end{array}$ \\
\hline
\end{tabular}

Źródło: opracowanie własne na podstawie informacji Komisji Europejskiej: [http://ec.europa.eu/ regional_policy/pl/policy/evaluations/data-for-research/, (data wejścia: 07.07.2016)]. 
W perspektywie 2004-2006, przewidziano wsparcie na badania i innowacje udzielane wyłącznie na poziomie krajowym (m.in.: SPO WKP, ZPORR), zaś w perspektywach 2007-2013 i 2014-2020 za pośrednictwem programów: krajowych, ponadregionalnych i regionalnych. Udział środków alokowanych na poziom regionalny w perspektywach 2007-2013 oraz 2014-2020 stanowił odpowiednio około 33\% oraz 31\%, natomiast udział alokacji na poziomie krajowym wynosił około 62\% i 65\% (w latach 2007-2013 i 2014-2020 udział około 5\% i 4\% dotyczył poziomu ponadregionalnego, tj. programu dla Polski Wschodniej).

Po 2004 roku nastąpiło wiele zmian dotyczących podmiotów odpowiedzialnych za wsparcie innowacyjności. W 2005 roku zlikwidowano Komitet Badań Naukowych, zaś jego zadania przejęło Ministerstwo Nauki i Informatyzacji, które z kolei w 2006 roku zostało przekształcone w Ministerstwo Nauki i Szkolnictwa Wyższego (MNiSW). W 2007 roku utworzono Narodowe Centrum Badań i Rozwoju (NCBR), do którego zadań należy realizacja strategicznych programów badań naukowych i prac rozwojowych, a także wsparcie badań stosowanych i prac rozwojowych (od 2011 roku - także wdrażania krajowych programów operacyjnych w zakresie badań naukowych i prac rozwojowych). W 2010 roku utworzono Narodowe Centrum Nauki, którego zadaniem jest finansowanie badań podstawowych. W efekcie finansowanie konkursowe badań naukowych w przeważającej mierze zostało przeniesione na poziom wcześniej wspomnianych agencji rządowych. Jednocześnie działalność w zakresie wspierania innowacyjności realizowały: Ministerstwo Gospodarki i PARP, Bank Gospodarstwa Krajowego (m.in. kredyt technologiczny) oraz Agencja Rozwoju Przemysłu SA. Wyzwaniem, związanym ze wzrostem liczby podmiotów zaangażowanych w wsparcie badań i innowacji, stało się zapewnienie odpowiedniej koordynacji ich działań. Jednym z elementów wzmocnienia tej koordynacji było utworzenie Ministerstwa Rozwoju (połączenie resortów odpowiedzialnych za gospodarkę i rozwój regionalny) oraz powołanie Rady do spraw Innowacyjności i Komitetu Ekonomicznego Rady Ministrów w 2016 roku. Lepszej koordynacji działań na poziomie operacyjnym (wdrożeniowym) powinno również sprzyjać utworzenie Polskiego Funduszu Rozwoju, który koordynuje działalność m.in.: PARP, ARP SA i BGK.

Po 2004 roku powstało kilka dokumentów strategicznych na poziomie krajowym, które dotyczą badań i innowacji. Zestawienie najważniejszych z nich przedstawia tabela 4 . 
TABELA 4.

\section{Dokumenty strategiczne dotyczące innowacyjności w Polsce, w latach 2007-2015}

\begin{tabular}{|c|c|c|c|c|}
\hline Resort nauki & Resort gospodarki & \multicolumn{3}{|c|}{ Resort rozwoju regionalnego } \\
\hline $\begin{array}{l}\text { „Założenia polityki } \\
\text { naukowej, naukowo- } \\
\text { technicznej i inno- } \\
\text { wacyjnej Polski do } \\
2020 \text { roku” (Zatoże- } \\
\text { nia, grudzień 2004, } \\
\text { Ministerstwo Nauki i } \\
\text { Informatyzacji) }\end{array}$ & $\begin{array}{l}\text { „Kierunki zwiększa- } \\
\text { nia innowacyjności } \\
\text { polskiej gospodarki } \\
\text { w latach 2007-2013” } \\
\text { (Kierunki, sierpień } \\
\text { 2006, Ministerstwo } \\
\text { Gospodarki) }\end{array}$ & \multicolumn{2}{|c|}{$\begin{array}{l}\text { „Strategia rozwoju kraju do } 2015 \\
\text { roku” (SRK I, listopad 2006, Minis- } \\
\text { terstwo Rozwoju Regionalnego) }\end{array}$} & $\begin{array}{l}\text { „Narodowe Strate- } \\
\text { giczne Ramy Odnie- } \\
\text { sienia 2007-2013 } \\
\text { wspierające wzrost } \\
\text { gospodarczy i zatrud- } \\
\text { nienie. Narodowa Stra- } \\
\text { tegia Spójności” (maj } \\
\text { 2007, Ministerstwo } \\
\text { Rozwoju Regional- } \\
\text { nego) }\end{array}$ \\
\hline $\begin{array}{l}\text { „Strategia rozwoju } \\
\text { nauki w Polsce do } \\
2015 \text { roku” (doku- } \\
\text { ment nie został przy- } \\
\text { jęty przez Radę Mi- } \\
\text { nistrów, zaś jego ma- } \\
\text { teria została włączo- } \\
\text { na do SIiEG) }\end{array}$ & $\begin{array}{l}\text { „Strategia innowacyj- } \\
\text { ności i efektywności } \\
\text { gospodarki. Dyna- } \\
\text { miczna Polska 2020" } \\
\text { (SIiEG, styczeń 2013, } \\
\text { Ministerstwo Gos- } \\
\text { podarki) }\end{array}$ & $\begin{array}{l}\text { "Strategia roz- } \\
\text { woju kraju 2020" } \\
\text { (SRK II, wrze- } \\
\text { sień 2012, Mi- } \\
\text { nisterstwo Roz- } \\
\text { woju Regional- } \\
\text { nego) }\end{array}$ & $\begin{array}{l}\text { „Krajowa strate- } \\
\text { gia rozwoju re- } \\
\text { gionalnego" } \\
\text { (KSRR, lipiec } \\
\text { 2010, Minister- } \\
\text { stwo Rozwoju } \\
\text { Regionalnego) }\end{array}$ & $\begin{array}{l}\text { "Umowa Partnerstwa } \\
\text { 2014-2020" (maj 2014, } \\
\text { Ministerstwo Infra- } \\
\text { struktury i Rozwoju) }\end{array}$ \\
\hline
\end{tabular}

Źródło: opracowanie własne.

Dokumenty strategiczne podane w tabeli 4. podkreślały konieczność większego zaangażowania w przedsięwzięcia $\mathrm{i}$ inicjatywy międzynarodowe związane $\mathrm{z}$ badaniami i innowacjami, a także wzmocnienia działań podejmowanych na poziomie regionalnym [Strategia Rozwoju Kraju..., 2006, s. 28, 57]. Dotyczy to zwłaszcza:

- $\quad$ znaczenia regionalnych strategii innowacji przyczyniających się do: rozwoju regionalnego i lokalnego, tworzenia nowych miejsc pracy, a przede wszystkim określania przez regiony własnych priorytetów w polityce innowacyjnej [Kierunki zwiekszania innowacyjności gospodarki..., 2006, s. 63; Strategia Innowacyjności i Efektywności Gospodarki..., 2013, s. 65];

- $\quad$ konieczności: budowy interaktywnego modelu polityki innowacyjnej na poziomie krajowym i regionalnym, indywidualnego doboru zestawu instrumentów polityki innowacyjnej na poziomie regionalnym, zwiększania roli regionów w tworzeniu warunków do rozwoju przedsiębiorstw innowacyjnych [Kierunki zwiekeszania innowacyjności..., 2006, s. 15];

- $\quad$ potrzeby wzmocnienia koordynacji działań różnych instytucji w zakresie polityki innowacyjnej [Kierunki zmiekeszania innowacyjności gospodarki..., 2006, s. 49; Strategia Innowacyjności i Efektywności Gospodarki..., 2013, s. 46].

Wieloszczeblowe zarządzanie procesami rozwoju regionalnego stało się również jedną z podstawowych zasad polityki regionalnej. Zgodnie z Krajowa Strategia Rozwoju Regionalnego [2010, s. 79], urzeczywistnienie realizacji zasady wieloszczeblowego zarządzania procesami rozwoju regionalnego będzie wiązało się z: zorganizowaniem systemu zarzadzania i realizacji polityki regionalnej w oparciu o wypracowana zinstytucjonalizowana sieć złożona ze spójnych elementów jednego systemu: poziom europejski - krajowy - regionalny - lokalny, umożliwiajaca więkesze zaangażowanie partnerów spoleczno-gospodarczych działajacych na rzecz. rozwoju regionalnego. 
Do wieloszcrzeblowego współdecydowania nawiązuje także „Strategia na rzecz Odpowiedzialnego Rozwoju”. Wprawdzie wprost nie odnosi się do współzarządzania wielopoziomowego w zakresie badań i innowacji, ale określa działania dotyczące: wzmocnienia koordynacji, spójności i synergii wsparcia badań i innowacji [Strategia na ržecz. Odpowiedzialnego Rozwoju..., 2017, s. 70, 286].

Od 2007 roku wsparcie finansowe działalności badawczo-rozwojowej (głównie infrastruktura badawcza) $\mathrm{i}$ innowacyjnej jest realizowane przez Urzędy Marszałkowskie lub podległe im jednostki, w tym agencje rozwoju regionalnego. Dokumentami, określającymi cele strategiczne w obszarze badań $\mathrm{i}$ innowacji na poziomie regionalnym, sa regionalne strategie innowacji, a także regionalne strategie inteligentnych specjalizacji, których opracowanie warunkuje dostęp do europejskich funduszy strukturalnych $i$ inwestycyjnych na badania $i$ innowacje w latach 2014-2020. Te ostatnie opieraja się na specyficznym dla każdego regionu podejściu do identyfikowania obszarów priorytetowych oraz zaangażowania interesariuszy w ich tworzenie. Równocześnie przewidują one różne mechanizmy implementacji, w tym rozmaite instrumenty wsparcia [W kierunku innowacyjnej Polski..., 2015, s. 13 i nast.]. Ich głównym (często jedynym) źródłem finansowania są środki z Unii Europejskiej.

Reasumując, przystapienie Polski do Unii Europejskiej przyczyniło się do „europeizacj”” i „regionalizacji” polityki innowacyjnej, przejawiającej się przeniesieniem pewnych działań z zakresu tej polityki na poziomy: ponadnarodowy i regionalny. W rezultacie wsparcie innowacji i inne działania z zakresu polityki innowacyjnej sa realizowane na poziomie: europejskim, krajowym, regionalnym i lokalnym (miast i gmin). Jednocześnie system wsparcia innowacyjności bazuje na coraz bardziej złożonych relacjach, w ramach których współpracuja podmioty publiczne i prywatne. Ten ostatni element jest szczególnie mocno akcentowany w krajowej strategii i regionalnych strategiach inteligentnych specjalizacji [Mieszkowski, Kardas, 2015, s. 375].

\section{Podsumowanie i dyskusja}

Po 1989 roku działalność władz publicznych w Polsce w zakresie wsparcia badań $i$ innowacji była przedmiotem wielu zmian, których efektem było wyłonienie się polityki innowacyjnej i kształtowanie współzarządzania wielopoziomowego w tej polityce. W wyniku tych zmian zwiększa się znaczenie ponadnarodowych, regionalnych i lokalnych struktur władzy. Rośnie także aktywność regionalnych oraz lokalnych podmiotów wspierających innowacyjność, które są podmiotami niezależnymi od władz rządowych i samorządowych (np.: agencji, fundacji, stowarzyszeń). Podmioty te współpracuja w układzie horyzontalnym i wertykalnym, również przy opracowywaniu regionalnych i lokalnych dokumentów strategicznych w zakresie badań i innowacji. Obecne uwarunkowania polityki innowacyjnej w Polsce z perspektywy współzarządzania wielopoziomowego przedstawia tabela 5. 
TABELA 5.

Polityka innowacyjna w Polsce z perspektywy współzarządzania wielopoziomowego - obecne uwarunkowania

\begin{tabular}{|c|c|c|c|c|c|}
\hline & $\begin{array}{c}\text { Poziom } \\
\text { europejski }\end{array}$ & $\begin{array}{l}\text { Poziom } \\
\text { krajowy }\end{array}$ & $\begin{array}{l}\text { Poziom } \\
\text { ponadre- } \\
\text { gionalny }\end{array}$ & $\begin{array}{l}\text { Poziom } \\
\text { regionalny }\end{array}$ & $\begin{array}{l}\text { Poziom } \\
\text { lokalny } \\
\text { (miejski) }\end{array}$ \\
\hline $\begin{array}{l}\text { Instytucje two- } \\
\text { rzące politykę } \\
\text { innowacyjną }\end{array}$ & $\begin{array}{l}\text { Parlament Eu- } \\
\text { ropejski, Komi- } \\
\text { sja Europejska }\end{array}$ & $\begin{array}{l}\text { Sejm i Senat } \\
\text { RP, MNiSW, } \\
\text { MR }\end{array}$ & $\begin{array}{l}\text { Samorząd regio- } \\
\text { nalny }\end{array}$ & $\begin{array}{l}\text { Samorząd regio- } \\
\text { nalny }\end{array}$ & $\begin{array}{l}\text { Samorząd lokal- } \\
\text { ny }\end{array}$ \\
\hline $\begin{array}{l}\text { Partnerzy spo- } \\
\text { łeczni i gospo- } \\
\text { darczy (przy- } \\
\text { kłady) }\end{array}$ & $\begin{array}{l}\text { Europejskie } \\
\text { platformy } \\
\text { technologic- } \\
\text { zne, EIRMA }\end{array}$ & $\begin{array}{l}\text { Stowarzysze- } \\
\text { nie TOP } 500 \\
\text { Innovators, } \\
\text { Obywatele } \\
\text { Nauki, platfor- } \\
\text { my technolo- } \\
\text { giczne }\end{array}$ & $\begin{array}{l}\text { Regionalne Fo- } \\
\text { rum Inteligent- } \\
\text { nych Specjaliza- } \\
\text { cji }\end{array}$ & $\begin{array}{l}\text { Regionalne or- } \\
\text { ganizacje bran- } \\
\text { żowe i społecz- } \\
\text { ne }\end{array}$ & $\begin{array}{l}\text { Lokalne orga- } \\
\text { nizacje bran- } \\
\text { żowe i społecz- } \\
\text { ne }\end{array}$ \\
\hline $\begin{array}{l}\text { Dokumenty } \\
\text { strategiczne }\end{array}$ & $\begin{array}{l}\text { „Europa 2020”, } \\
\text { Inicjatywa prze- } \\
\text { wodnia - Unia } \\
\text { Innowacji }\end{array}$ & $\begin{array}{l}\text { SRK, SIiEG, } \\
\text { Strategia na } \\
\text { rzecz Odpo- } \\
\text { wiedzialnego } \\
\text { Rozwoju (SOR) }\end{array}$ & $\begin{array}{l}\text { Strategie ponad- } \\
\text { regionalne (Pol- } \\
\text { ski Wschodniej, } \\
\text { Centralnej, Po- } \\
\text { łudniowej, Za- } \\
\text { chodniej) }\end{array}$ & $\begin{array}{l}\text { Strategie regio- } \\
\text { nalne, regional- } \\
\text { ne strategie in- } \\
\text { nowacji }\end{array}$ & $\begin{array}{l}\text { Strategie miast, } \\
\text { np. Innowacyj- } \\
\text { na Warszawa }\end{array}$ \\
\hline $\begin{array}{l}\text { Priorytety te- } \\
\text { matyczne }\end{array}$ & $\begin{array}{l}\text { Priorytety te- } \\
\text { matyczne wska- } \\
\text { zywane w pro- } \\
\text { gramach ra- } \\
\text { mowych }\end{array}$ & $\begin{array}{l}\text { Krajowa Inte- } \\
\text { ligentna Spe- } \\
\text { cjalizacja, Kra- } \\
\text { jowy Program } \\
\text { Badań }\end{array}$ & $\begin{array}{l}\text { Wspólne obszary } \\
\text { wskazane w regio- } \\
\text { nalnych strate- } \\
\text { giach inteligen- } \\
\text { tnych specjaliza- } \\
\text { cji }\end{array}$ & $\begin{array}{l}\text { Regionalne stra- } \\
\text { tegie inteligent- } \\
\text { nej specjaliza- } \\
\text { cji }\end{array}$ & $\begin{array}{l}\text { Zwykle nie } \\
\text { określają prio- } \\
\text { rytetów tema- } \\
\text { tycznych. }\end{array}$ \\
\hline $\begin{array}{l}\text { Instytucje } \\
\text { wdrażające }\end{array}$ & $\begin{array}{l}\text { Europejska } \\
\text { Rada do spraw } \\
\text { Badań Nauko- } \\
\text { wych, Europej- } \\
\text { ski Bank In- } \\
\text { westycyjny }\end{array}$ & $\begin{array}{l}\text { NCBR, NCN, } \\
\text { PARP, ARP } \\
\text { S.A., BGK, } \\
\text { PFR }\end{array}$ & $\begin{array}{l}\text { Brak odrębnych } \\
\text { instytucji }\end{array}$ & $\begin{array}{l}\text { Urzędy Mar- } \\
\text { szałkowskie } \\
\text { i podległe im } \\
\text { podmioty } \\
\text { (np. agencje } \\
\text { rozwoju regio- } \\
\text { nalnego) }\end{array}$ & $\begin{array}{l}\text { Urzędy Miej- } \\
\text { skie }\end{array}$ \\
\hline $\begin{array}{l}\text { Programy } \\
\text { wsparcia }\end{array}$ & $\begin{array}{l}\text { Program } \\
\text { „Horyzont } \\
2020 ” \\
\text { i Program } \\
\text { COSME }\end{array}$ & $\begin{array}{l}\text { Programy kra- } \\
\text { jowe (progra- } \\
\text { my NCN, pro- } \\
\text { gramy strate- } \\
\text { giczne NCBR) } \\
\text { i współfinan- } \\
\text { sowane przez } \\
\text { Unię Europej- } \\
\text { ską (POIR) }\end{array}$ & $\begin{array}{l}\text { Brak odrębnych } \\
\text { programów wspar- } \\
\text { cia (programy } \\
\text { krajowe lub re- } \\
\text { gionalne) - wy- } \\
\text { jątek Program } \\
\text { Operacyjny Pol- } \\
\text { ska Wschodnia }\end{array}$ & $\begin{array}{l}\text { Regionalne } \\
\text { Programy } \\
\text { Operacyjne, } \\
\text { programy eu- } \\
\text { ropejskie (np. } \\
\text { INTERREG) }\end{array}$ & $\begin{array}{l}\text { Programy eu- } \\
\text { ropejskie (np. } \\
\text { INTERREG), } \\
\text { środki własne } \\
\text { samorządów }\end{array}$ \\
\hline $\begin{array}{l}\text { Instrumenty } \\
\text { wsparcia }\end{array}$ & $\begin{array}{l}\text { Dotacje, instru- } \\
\text { menty zwrot- } \\
\text { ne, zamówie- } \\
\text { nia przedko- } \\
\text { mercyjne }\end{array}$ & $\begin{array}{l}\text { Dotacje, instru- } \\
\text { menty zwrot- } \\
\text { ne, ulgi podat- } \\
\text { kowe, zamó- } \\
\text { wienia publicz- } \\
\text { ne i przedko- } \\
\text { mercyjne }\end{array}$ & $\begin{array}{l}\text { Dotacje, instru- } \\
\text { menty zwrotne }\end{array}$ & $\begin{array}{l}\text { Dotacje, instru- } \\
\text { menty zwrot- } \\
\text { ne, zamówie- } \\
\text { nia publiczne }\end{array}$ & $\begin{array}{l}\text { Dotacje, zamó- } \\
\text { wienia publicz- } \\
\text { ne }\end{array}$ \\
\hline
\end{tabular}

Źródło: opracowanie własne.

W ostatnich latach system wsparcia innowacji w Polsce staje się coraz bardziej złożony zarówno pod względem poziomów i instrumentów wsparcia, jak i podmiotów zaan- 
gażowanych w ich wdrażanie. Mimo rosnącego znaczenia poziomu ponadnarodowego i regionalnego, ze względu na skalę środków przeznaczanych na finansowanie badań i innowacji oraz oddziaływanie poprzez instrumenty pozafinansowe (legislacyjne) dominująca rolę nadal odgrywa poziom krajowy.

Współzarządzanie wielopoziomowe w krajowej polityce innowacyjnej niesie ze sobą wiele wyzwań, zwłaszcza w kontekście realizacji postulatów wynikających z Karty Wielopoziomowego Sprawowania Rz̨adów. Podstawowe znaczenie ma kwestia źródeł finansowania w ramach polityki innowacyjnej, zwłaszcza na poziomie regionalnym. Można w tym kontekście zadać pytanie: jak współzarządzanie wielopoziomowe w zakresie badań $\mathrm{i}$ innowacji w Polsce wyglądałoby bez wsparcia finansowego regionów ze strony Unii Europejskiej? $\mathrm{Na}$ poziomie regionalnym środki z europejskich funduszy strukturalnych i inwestycyjnych stanowią bowiem podstawowe (w niektórych regionach - jedyne) źródło wsparcia działalności badawczej i innowacyjnej, a także umożliwiają realizację regionalnych strategii innowacji oraz regionalnych strategii inteligentnej specjalizacji. Krajowe doświadczenia z lat 2000-2006 pokazują że brak środków na realizację zadań wspierających innowacyjność na poziomie regionalnym istotnie ogranicza lub uniemożliwia wdrażanie regionalnych strategii innowacji. Pytanie związane z finansowaniem regionalnej polityki innowacyjnej stanie się szczególnie aktualne po 2020 roku, ale w praktyce rodzi konieczność poszukiwania już dziś odpowiedzi na pytania dotyczące: celów, zadań i odpowiadających im instrumentów wsparcia w odniesieniu do różnych poziomów interwencji (np. centralizacja vs. decentralizacja) oraz różnych mechanizmów wsparcia badań i innowacji (dotacje, instrumenty zwrotne, ulgi podatkowe). Wielopoziomowość systemu wsparcia badań i innowacji będzie wymagać odpowiedniej koordynacji działań realizowanych na różnych poziomach przez wiele podmiotów oraz zapewnienia spójności i synergii oferowanego przez nie wsparcia, w tym określenia roli: agencji rozwoju regionalnego, specjalnych stref ekonomicznych, jak również podmiotów niepublicznych zaangażowanych we wspieranie innowacyjności i rozwoju lokalnego lub regionalnego (np.: klastry, komercyjne inkubatory i organizacje wspierające transfer technologii). Słabości w zakresie koordynacji w polityce innowacyjnej w Polsce były podnoszone już w latach dziewięćdziesiątych minionego wieku, zaś postępujący z czasem wzrost liczby poziomów i podmiotów zaangażowanych w jej tworzenie i wdrażanie czyni system wsparcia innowacyjności jeszcze bardziej złożonym. Pod tym względem bardzo cenne mogą okazać się wnioski i doświadczenia związane z realizowanymi obecnie przez NCBR dwoma instrumentami wsparcia, tj.: Regionalnymi Agendami Naukowo-Badawczymi oraz programami sektorowymi. Pierwszy obejmuje wsparcie projektów badawczych jednostek naukowych wynikających $\mathrm{z}$ regionalnych inteligentnych specjalizacji: regiony zgłaszaja $\mathrm{w}$ nim propozycje tematów badawczych wynikających z regionalnych strategii inteligentnej specjalizacji, które następnie stanowia zakres tematyczny konkursu w działaniu 4.1.2 POIR - prowadzonego przez NCBR. Rozwiązanie to umożliwia z jednej strony uwzględnienie zagadnień badawczych istotnych $z$ punktu widzenia regionów (decentralizacja), z drugiej wyeliminowanie zjawiska powielania wsparcia tych samych lub podobnych projektów oraz zapewnienie wysokiej jakości dofinansowywanych projektów naukowych (centralizacja). Instrument ten jest przykładem powiązania wymiaru regionalnego i krajowego 
we wspieraniu badań i innowacji. Z kolei, programy sektorowe eksponuja aspekt partycypacyjny i współpracę ze środowiskami branżowymi (np.: platformami technologicznymi, klastrami branżowymi) przy definiowaniu agend badawczych oraz ich współfinansowaniu ze środków publicznych [Mieszkowski, Kardas, 2015, s. 375]. Zarówno Regionalne Agendy Naukowo-Badawcze, jak i programy sektorowe sa przykładami instrumentów wsparcia, w których elementem integrującym różne poziomy sprawowania rządów lub aktywność różnych interesariuszy jest wypracowanie wspólnego zakresu tematów badawczych (agenda badawcza), istotnych z punktu widzenia środowisk branżowych lub regionów. Wagę współpracy i koordynacji działań w polityce innowacyjnej podkreśla również „Strategia na rzecz Odpowiedzialnego Rozwoju”, zaś formułowane w niej propozycje, np. regionalnych funduszy rozwoju, mogą być kolejnym mechanizmem integrującym aktywność instytucji krajowych i regionalnych [Strategia na ręecz. Odpowiedrialnego Rozwoju..., 2017, s. 157].

Współrządzenie wielopoziomowe w polityce innowacyjnej stanowi duże wyzwanie badawcze. Omawiana tematyka była przedmiotem wielu badań, opracowań i raportów, ale miały one charakter teoretyczny bądź skupiały się na analizie studiów przypadków [Regions and Innovation Policy, 2011, s. 144-146]. Nie dają one jednak jednoznacznej odpowiedzi na pytania związane z wpływem współzarządzania wielopoziomowego na: wzrost gospodarczy, konkurencyjność, innowacyjność czy jakość rządzenia państw i regionów. Jednym z głównych ograniczeń przy poszukiwaniu odpowiedzi na pytania dotyczące skuteczności i efektywności współzarządzania wielopoziomowego był i wciąż pozostaje brak odpowiednich danych, na podstawie których można byłoby prowadzić analizy i badania w tym zakresie [Guimon, 2013, s. 3]. W artykule skupiono się przede wszystkim na kwestiach wielopoziomowości (zwłaszcza z perspektywy krajowej), a w mniejszym stopniu na współpracy różnych podmiotów i partnerstwie (wspólnym sprawowaniu rządów). Należy oczekiwać, że w przyszłości prowadzone badania przyczynią się do pogłębienia wiedzy na temat tego zagadnienia oraz będą stanowić zasadnicze wsparcie dla polityków i interesariuszy zaangażowanych we współzarządzanie wielopoziomowe w polityce innowacyjnej.

\section{Literatura}

Bonaccorsi A., 2009, Towards better use of conditionality in policies for research and innovation under structural funds, Report Working Paper.

Cooke P., 2002, Regional Innovation Systems: General Findings and Some New Evidence from Biotechnology Clusters, "Journal of Technology Transfer", no. 27.

Dziemianowicz W., Gawlikowska-Huecel K., Lodkowska-Skoneczna K., Pyszkowski A., Szlachta J., 1999, Rozwój regionalny jako element strategii społeczno-gospodarczej Polski w latach 2000-2006, „Polska Regionów”, nr 6, Gdańsk-Warszawa.

Edquist Ch., Borras S., 2013, The Choice of Innovation Policy Instruments, Paper, no. 04, CIRCLE, Lund University.

Frączek M., 2014, Praktyka realizacij polityki rynku pracy w Polsce a wspótzarzqudzanie publiczne, „Zarządzanie Publiczne”, nr 2(32). 
Gorzelak G., Bąkowski A., Kozak M., Olechnicka A., 2006, Polskie regionalne strategie innowacji: ocena i wnioski dla dalszych driałań, Regional Studies Association - Sekcja Polska, Warszawa.

Gorzelak G., Kozak M., Roszkowski W., 1997, Agencje rozwoju regionalnego w Polsce, [w:] Przemiany polskiej przestrzeni, G. Gorzelak (red.), Uniwersytet Warszawski, Europejski Instytut Rozwoju Regionalnego i Lokalnego, Warszawa.

Guimon J., 2013, Smart Decentralisation of Innovation Policies, Policy Brief, The Innovation Policy Platform, OECD - World Bank.

Hausner J., 2008, Zarzadzanie publiczne, Wydawnictwo Naukowe SCHOLAR, Warszawa.

Hooghe L., Marks G., 2003, Unraveling the Central State, but How? Types of multi-level governance, "The American Political Science Review", vol. 97, no. 2.

Jabłecka J., 2009, Finansowanie badań ze źródeł publicznych. Rady badawcze, instrumenty finansowania, ewolucja systemu w Polsce, Centrum Badań Polityki Naukowej i Szkolnictwa Wyższego, Uniwersytet Warszawski, Warszawa.

Jasiński A. H., 1997, Innowacje i polityka innowacyjna, Wydawnictwo Uniwersytetu w Białymstoku, Białystok.

Jasiński A. H., 2006, Innowacje $i$ transfer techniki w procesie transformacji, Wydawnictwo Difin, Warszawa.

Jasiński A.H., Okoń-Horodyńska E., 2002, Innovation in Transition. The case of Poland, Wydawnictwo Naukowe Wydziału Zarządzania Uniwersytetu Warszawskiego, Warszawa.

Kierunki zwiekeszania innowacyjności gospodarki na lata 2007-2013, 2006, Ministerstwo Gospodarki, Warszawa.

Komisja Europejska, http://ec.europa.eu/regional_policy/pl/policy/evaluations / data-for-research/ (data wejścia: 07.07.2016).

Kopyciński P., 2014, Mechaniżm koordynacji w polityce innowacyjnej w świetle koncepcji wspókzarzqdzania wielopoziomowego (multi-levelgovernance). Prayketad województw matopolskiego i śmietokrayskiego, „Zarządzanie Publiczne”, nr 4(30).

Koschatzky K., Kroll H., 2009, Multi-levelgovernance in innovationsystems, „Ekonomiaz”, no. 70 .

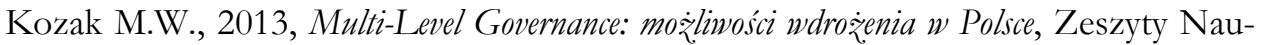
kowe WSEI, seria: EKONOMIA, nr 6.

Krajowa Strategia Rozwoju Regionalnego, 2010, Ministerstwo Rozwoju Regionalnego, Warszawa.

Kuhlmann S., 2001, Future governance of innovation policy in Europe - three scenarios, "Research Policy", no. 30.

Magro E., Wilson J.R., 2013, Complex innovation policy systems: Towards an evaluation mix, "Research Policy", no. 42.

Marks G., 1993, Structural Policy and Multi-level Governance in the EC, [in:] The State of the European Community, A. Cafruny, G. Rosenthal (eds.), Lynne Rienner, Boulder, CO.

Miedziński M., 2001, Koordynacja procesów innowacji na prayktadzie polskiego wojewódz̨twa. Aspekty instytucjonalne regionalnych systemów innowacji, [w:] Gospodarka oparta na wiedzy. 
Wyzwanie dla Polski XXI wieku, A. Kukliński (red.), Komitet Badań Naukowych, Warszawa.

Mieszkowski K., Kardas M., 2015, FacilitatinganEntrepreneurial Discovery Processfor Smart Specialisation Strategy. The case of Poland, "Journal of Knowledge Economy", no. 6,.

Narodowa Strategia Rozwoju Regionalnego 2001-2006, 2000, Ministerstwo Gospodarki, Warszawa.

Narodowy Plan Rozwoju 2004-2006, 2003, Ministerstwo Gospodarki, Pracy i Polityki Społecznej, Warszawa.

Nowakowska A., 2009, Zdolności innowacyjne polskich regionów, Wydawnictwo Uniwersytetu Lódzkiego, Lódź.

Okoń-Horodyńska E., 1998, Narodowy System Innowacii w Polsce, Wydawnictwo Uczelniane Akademii Ekonomicznej w Katowicach, Katowice.

Piattoni S., 2009, Multi-Level Governance in the EU. Does it work?, MIT, no. 8/9 maja.

Polityka przemystowa. Założenia. Program realizacji w latach 1993-1995, 1994, Ministerstwo Przemysłu i Handlu, Warszawa.

Program wspierania rozwoju instytucji regionalnych działajacych na rzecz, transferu technologii, 1997, Ministerstwo Gospodarki, Warszawa.

Przeglad Narodowej Polityki Naukowej i Technicznej Polska, 1996, OECD KBN, Warszawa.

Regions and Innovation Policy, 2011, OECD Reviews of Regional Innovation, OECD Publishing, Paris.

Rezolucja w sprawie Karty Wielopoziomowego Sprawowania Rzqdów w Europie, 2014, Komitet Regionów, RESOL-V-012, 106 sesja plenarna w dniach 2-3 kwietnia 2014 ro$\mathrm{ku}$, Bruksela.

Rodrigo D., Allio L., Andres-Amo P., 2009, Multilevel Regulatory Governance, OECD Working Papers on Public Governance, no. 13.

Rozporzadzenie 1303/2013 ₹ 13 grudnia 2013 roku ustanawiajace wspólne przepisy dotyczqce Europejskiego Funduszu Rozwoju Regionalnego, Europejskiego Funduszu Spotecznego, Fundusqu Spójności, Europejskiego Funduszu Rolnego na rzecz Rozwoju Obszarów Wiejskich oraz Europejskiego Funduszu Morskiego i Rybackiego oraz ustanawiajace przepisy ogólne dotyczace Europejskiego Funduszu Rozwoju Regionalnego, Europejskiego Funduszu Społecznego, Funduszu Spójności i Europejskiego Funduszu Morskiego i Rybackiego oraz uchylajace rozporzqdzenie Rady (WE) nr 1083/2006 (Dz. UE L 347/320 z 20.12.2013).

Ruszkowski J., 2013, Struktura wielopoziomowego zarzadzania w Unï Europejskiej, [w:] Multi-level governance w Unii Europejskiej, J. Ruszkowski, L. Wojnicz (red.), Instytut Europeistyki Uniwersytetu Warszawskiego, Szczecin-Warszawa.

Schmitter P. C., 2002, Neo-neo-functionalism, European University Institute, Florence.

Strategia Innowacyjności i Efektywności Gospodarki - Dynamiczna Polska 2020, 2013, Ministerstwo Gospodarki, Warszawa.

Strategia na rzecz Odpowiedzialnego Rozwoju, 2017, Ministerstwo Rozwoju, Warszawa.

Strategia Rozwoju Kraju 2007-2015, 2006, Ministerstwo Rozwoju Regionalnego, Warszawa.

Strategia Rогшоји Kraju 2020, 2012, Ministerstwo Rozwoju Regionalnego, Warszawa. 
Strategia rozwoju nauki w Polsce do 2015 roku, 2009, Ministerstwo Nauki i Szkolnictwa Wyższego, Warszawa (dokument nie został przyjęty przez Radę Ministrów).

Szlachta J., 1993, Rozwój regionalny Polski w warunkach transformacji gospodarczej, Polityka Ekonomiczna i Społeczna, Warszawa.

The Innovation Imperative, 2015, OECD Publishing, Paris.

W kierunku innowacyjnej Polski: Proces przedsiebiorczego odkrywania i analiza potrzeb przedsiebiorstw w Polsce, 2015, Bank Światowy, Warszawa.

Wstęny Narodowy Plan Rozpoju 2000-2003, 1999 (uzup. 2002), Komitet Integracji Europejskiej, Warszawa.

Założenia polityki innowacyjnej państwa do 2002 roku, 1999, Komitet Badań Naukowych, Warszawa.

Założenia polityki naukowej i naukowo-technicznej państwa, 1993, Komitet Badań Naukowych, Warszawa.

Założenia polityki naukowej, naukowo-technicznej i innowacyjnej Polski do 2020 roku, 2004, Ministerstwo Nauki i Informatyzacji, Warszawa.

Założenia strategii i polityki rozwoju przemystu do roku 2010 roku, 1996, Ministerstwo Przemysłu i Handlu, Warszawa.

Zwiekszanie innowacyjności gospodarki w Polsce do 2006 roku, 2000, Ministerstwo Gospodarki, Warszawa. 